\title{
Modulation of the transient receptor potential channel TRPA1 by phosphatidylinositol 4,5-biphosphate manipulators
}

\author{
Yuji Karashima • Jean Prenen • Victor Meseguer • \\ Grzegorz Owsianik • Thomas Voets • Bernd Nilius
}

Received: 3 February 2008 / Accepted: 5 March 2008

(C) Springer-Verlag 2008

\begin{abstract}
The transient receptor potential channel of the ankyrin-binding repeat subfamily, TRPA1, is a $\mathrm{Ca}^{2+}$ permeable non-selective cation channel that depolarizes the plasma membrane and causes $\mathrm{Ca}^{2+}$ influx. A typical feature of TRPA1 is its rapid desensitization following activation by agonists such as mustard oil (MO), cinnamaldehyde, and a high intracellular $\mathrm{Ca}^{2+}$ concentration. In whole-cell recordings on Chinese hamster ovary (CHO) cells expressing TRPA1, desensitization was delayed when phosphatidylinositol 4,5-biphosphate $\left(\mathrm{PIP}_{2}\right)$ was supplemented via the patch pipette, whereas the $\mathrm{PIP}_{2}$ scavenger neomycin accelerated desensitization. Preincubation with the PI-4 kinase inhibitor wortmannin reduced both constitutive TRPA1 channels activity and the response to MO. Run down was also accelerated by high intracellular $\mathrm{Mg}^{2+}$ concentrations, whereas chelating intracellular $\mathrm{Mg}^{2+}$ with $10 \mathrm{mM}$ ethylenedinitrilotetraacetic acid (EDTA) increased the basal channel activity. In inside-out patches, we observed a rapid run down of TRPA1 activity, which could be prevented by application of diC8-PIP 2 or $2 \mathrm{mM} \mathrm{Mg-ATP}$ but not $\mathrm{Na}_{2}$-ATP to the cytosolic side of the excised patches. In isolated trigeminal ganglion neurons, preincu-
\end{abstract}

Electronic supplementary material The online version of this article (doi:10.1007/s00424-008-0493-6) contains supplementary material, which is available to authorized users.

Y. Karashima · J. Prenen · G. Owsianik $\cdot$ T. Voets $\cdot$ B. Nilius $(\varangle)$ KU Leuven Department of Mol. Cell Biology,

Lab Ion Channel Research, Campus Gasthuisberg,

Herestraat 49, bus 802, B-3000 Leuven, Belgium

e-mail: bernd.nilius@med.kuleuven.be

\section{Meseguer}

Instituto de Neurociencias de Alicante, Universidad Miguel Hernandez-Consejo Superior de Investigaciones Cientificas, 03550 San Juan de Alicante, Spain bation with wortmannin resulted in inhibition of endogenous TRPA1 activation by MO. Taken together, our data indicate that $\mathrm{PIP}_{2}$ modulates TRPA1, albeit to a lesser extent than other known PIP $_{2}$-dependent TRP channels, and that tools modifying the plasma membrane $\mathrm{PIP}_{2}$ content often have direct effects on this channel.

Keywords TRP channels · Non-selective cation channels . TRPA1 - Phosphoinositol phosphates .

Phosphatidylinositol 4, 5-biphosphate $\cdot \mathrm{PIP}_{2}$

\section{Introduction}

TRPA1 is the only mammalian member of the TRPA subfamily. It is expressed in the dorsal root ganglion and trigeminal ganglion (TG) neurons, where it is involved in nociception $[3,55]$. It is also expressed in non-sensory tissue such as inner ear $[9,38]$ and in low abundance in the small intestine, colon, skeletal muscle, heart, brain, and components of the immune system [54]. Initial reports [3, 55] claimed TRPA1 to be activated by the noxious cold $\left(<17^{\circ} \mathrm{C}\right)$; however, at this point, it remains uncertain whether TRPA1 actually functions as a cold sensor $[5,19,38,50]$. Indirect support for a thermosensitive function of TRPA1 derives from recent reports showing that antisense knockout of TRPA1 alleviates cold hyperalgesia subsequent to spinal nerve ligation [21] and that the upregulation of the channel in sensory neurones following injury and inflammation contributes to cold hyperalgesia [41]. Unfortunately, the recent, independent generation of two TRPA1 knockout mouse models has not settled the controversy regarding whether TRPA1 could be activated by the noxious cold [5, 24].

In contrast, the activation of TRPA1 by a diversity of chemical agents is widely accepted. Chemical activators of 
TRPA1 include isothiocyanates (allylisothiocyanate), the pungent compounds in mustard oil (MO), wasabi, and horseradish [3, 19], methyl salicylate (from winter green oil) [3], cinnamaldehyde (from cinnamon) [3], allicin and diallyl disulphide (from garlic) [5, 32], acrolein (an irritant in vehicle exhaust fumes and tear gas) [5], and $\Delta^{9}$ tetrahydrocannabinol $\left(\Delta^{9}\right.$-THC, the psychoactive compound in marijuana) [19]. TRPA1 has also been reported to be insensitive to the TRPV1 activator capsaicin [43, 55], but the well-known TRPM8 agonist menthol also activates TRPA1 at low concentrations, whereas high concentrations inhibit the current through TRPA1 [20, 34].

Many of the TRPA1 agonists are thiol-reactive electrophiles that activate TRPA1 through a covalent binding with cysteine residues in the $\mathrm{NH}_{2}$ terminus of TRPA1 [17, 33]. Such covalent modifications rather than structural similarities may account for the similar agonist action of compounds such as MO, allicin, or acrolein on TRPA1 (for a review see [7, 44]). In addition, endogenous messengers acting as electrophilic irritants have been described for activation of TRPA1 [4, 33, 35, 37, 58].

In contrast to many reports on the modulation of various TRP channels by phosphatidylinositol 4,5-biphosphate $\left(\mathrm{PIP}_{2}\right.$; see for reviews $\left.[46,48]\right)$, up to now there are only a few indications for modulation of TRPA1 function by $\mathrm{PIP}_{2}$. First, $\mathrm{Ca}^{2+}$-dependent desensitization of TRPA1 following activation might be linked to $\mathrm{PIP}_{2}$ depletion by PLC [11, 38, 47, 65]. Second, application of bradykinin induces moderate PLC-dependent activation of TRPA1 followed by a strong desensitization [3], which would be in line with channel run down due to $\mathrm{PIP}_{2}$ depletion. However, data on PIP 2 modulation of TRPA1 are controversial. Whereas one report claims that $\mathrm{PIP}_{2}$ inhibits TRPA1 [10], another report implies activation of TRPA1 by $\mathrm{PIP}_{2}[1]$ and a third claims that $\mathrm{PIP}_{2}$ has no effect [23]. However, none of the papers systematically studied the possible modulation of TRPA1 by $\mathrm{PIP}_{2}$. Here, we provide for the first time direct evidence that $\mathrm{PIP}_{2}$ modulates TRPA1 function, although weaker than described for other TRPs, e.g., TRPM4 [40]. We also show that some experimental manipulations commonly used to investigate the action of $\mathrm{PIP}_{2}$ have striking effects on TRPA1 itself and must be considered with caution.

\section{Materials and methods}

Cell culture and neuronal cells

The tetracycline-inducible Chinese hamster ovary (CHO) cells stably expressing mouse TRPA1 (kindly provided by Dr. A. Patapoutian, La Jolla, USA; for details see [55]) were grown in Dulbecco's modified Eagle's medium containing $10 \%(v / v)$ human serum, $1 \%(v / v)$ non-essential amino acids, $2 \mathrm{mM}$ L-glutamine, $2 \mathrm{U} / \mathrm{ml}$ penicillin, $2 \mathrm{mg} / \mathrm{ml}$ streptomycin, $100 \mu \mathrm{g} / \mathrm{ml}$ hygromycin $\mathrm{B}$, and $5 \mathrm{~g} / \mathrm{ml}$ blasticidin at $37^{\circ} \mathrm{C}$ in a humidity-controlled incubator with $5 \% \mathrm{CO}_{2}$. To induce expression of TRPA1, $0.5 \mu \mathrm{g} / \mathrm{ml}$ tetracycline was added to the culture medium, and cells were used 5-24 h after induction. Alternatively, regular CHO cells were grown in Ham's F12 containing 10\% $(v / v)$ human serum, $2 \mathrm{mM}$ L-glutamine, $2 \mathrm{U} / \mathrm{ml}$ penicillin, and $2 \mathrm{mg} / \mathrm{ml}$ streptomycin at $37^{\circ} \mathrm{C}$ in a humidity-controlled incubator with $5 \% \mathrm{CO}_{2}$ and then transiently transfected with mouse TRPA1 cloned in the bicistronic pCAGGSIRES-GFP vector using TransIT-293 transfection reagent (Mirus). Successfully transfected cells were identified by their green fluorescence and used between 16 and $24 \mathrm{~h}$ after transfection.

TG neurons from adult mice (postnatal months 1-3) were cultured as described previously [36]. In brief, mice were killed by inhalation of $100 \% \mathrm{CO}_{2}$ followed by rapid decapitation. After removal, ganglia were cut in small pieces and incubated for $45 \mathrm{~min}$ at $37^{\circ} \mathrm{C}$ in a dissociation solution containing (in $\mathrm{mM}$ ): $155 \mathrm{NaCl}, 1.5 \mathrm{~K}_{2} \mathrm{HPO}_{4}, 5.6$ $N$-(hydroxyethyl)piperazine- $N$ '-2-ethanesulfonic acid (HEPES), $4.8 \mathrm{Na}-\mathrm{HEPES}$, and 5 glucose. The solution also contained $0.07 \%$ collagenase type XI (Sigma-Aldrich, St. Louis, MO, USA) and $0.3 \%$ dispase (Invitrogen, Carlsbad, CA, USA). After incubation, tissue fragments were gently triturated with a fire-polished glass pipette, and the resultant suspension was centrifuged at $1,700 \mathrm{rpm}$ for $10 \mathrm{~min}$. The pellet obtained was resuspended and cultured in a medium containing: $89 \%$ minimum essential medium (MEM), 10\% fetal calf serum supplemented with 1\% MEM vitamins (Invitrogen), $100 \mu \mathrm{g} / \mu \mathrm{l}$ penicillin/streptomycin, and nerve growth factor (NGF; mouse 7S, $100 \mathrm{ng} / \mathrm{ml}$; Sigma-Aldrich). Cells were plated on poly-L-lysine-coated glass coverslips and used after 1 day in culture.

\section{Solutions}

The extracellular solution for whole-cell patch clamp measurements contained (in $\mathrm{mM}$ ) $156 \mathrm{NaCl}, 1.5 \mathrm{CaCl}_{2}, 1$ $\mathrm{MgCl}_{2}, 10$ HEPES, and 10 glucose buffered at $\mathrm{pH} 7.4$ with $\mathrm{NaOH}$. The pipette solution for whole-cell measurements and the bath solution for cell-attached and inside-out measurements contained (in $\mathrm{mM}$ ) $156 \mathrm{CsCl}, 1 \mathrm{MgCl}_{2}, 10$ HEPES, and 5 ethylene-glycol- $O, O^{\prime}$-bis(2-aminoethyl)- $N$, $N, N^{\prime}, N^{\prime}$-tetraacetic acid (EGTA), pH 7.2 with $\mathrm{CsOH}$. In some experiments, the $\mathrm{Ca}^{2+}$ concentration was adjusted to 100 or $250 \mathrm{nM}$ by adding appropriate amounts of $\mathrm{CaCl}_{2}$ calculated by the CaBuf program (ftp://ftp.cc.kuleuven.be/ $\mathrm{pub} /$ droogmans/cabuf.zip). The pipette solution containing $10 \mu \mathrm{M} \mathrm{Ca}^{2+}$ contained (in $\mathrm{mM}$ ) $156 \mathrm{CsCl}, 10$ HEPES, and $10 \mathrm{~N}$-hydroxyethyl-ethylenediaminetriacetic acid, $\mathrm{pH} 7.2$ 
with $\mathrm{CsOH}$. The $\mathrm{Ca}^{2+}(10 \mu \mathrm{M})$ and $\mathrm{Mg}^{2+}(1 \mathrm{mM})$ concentrations were adjusted by adding appropriate amounts of $\mathrm{CaCl}_{2}$ and $\mathrm{MgCl}_{2}$, respectively, calculated by the CaBuf program. For the pipette solution containing $10 \mathrm{mM} \mathrm{Mg}^{2+}$ or ethylenedinitrilotetraacetic acid (EDTA), $10 \mathrm{mM}$ of $\mathrm{MgCl}_{2}$ or EDTA, respectively, was added to the solution containing (in $\mathrm{mM}$ ) $156 \mathrm{CsCl}$ and 10 HEPES, and $\mathrm{pH} 7.2$ was adjusted with $\mathrm{CsOH}$. The pipette solution for inside-out measurements contained (in $\mathrm{mM}$ ) $150 \mathrm{NaCl}, 0.1$ $\mathrm{Mg}$, and 10 HEPES, pH 7.4 with $\mathrm{NaOH}$. Experiments were performed at room temperature $\left(22-25^{\circ} \mathrm{C}\right)$. DiC8-PIP ${ }_{2}$ was purchased from Echelon Biosciences (Salt Lake City, UT, USA), and mustard oil (allyl isothiocyanate), inorganic triphosphate $\left(\mathrm{PPP}_{\mathrm{i}}\right.$, see supplement), neomycin, wortmannin, PAO, poly-L-lysine, U73122, and U73433 from Sigma (St. Louis, MO, USA).

\section{Electrophysiology}

Currents were measured using an EPC-7 or EPC-9 patchclamp amplifier (HEKA Elektronik, Lambrecht, Germany). Patch electrodes had a DC resistance between 2 and $4 \mathrm{M} \Omega$ when filled with the different recording solutions, and between $50 \%$ and $80 \%$ of the series resistance was electronically compensated to minimize voltage errors. Currents were sampled at $2.5-5 \mathrm{kHz}$ and filtered off-line at $1-5 \mathrm{kHz}$. The ramp protocol consisted of a $400-\mathrm{ms}$ ramp from -100 to $+100 \mathrm{mV}$ or a 500 -ms ramp from -150 to $+150 \mathrm{mV}$ from a holding potential of $0 \mathrm{mV}$ applied every $1.5 \mathrm{~s}$. In single channel measurements, we estimated open channel probability at a constant membrane potential because of the undefined number of channel in the patch, from Gaussian fits of the single channel amplitude histograms as $P_{\text {open }}=1-P_{\text {closed }}$.

\section{Measurement of intracellular $\mathrm{Ca}^{2+}$}

Cells were incubated with $2 \mu \mathrm{M}$ Fura-2 acetoxymethyl ester for $30 \mathrm{~min}$ at $37^{\circ} \mathrm{C}$. The fluorescent signal was measured upon alternating illumination at 350 and $380 \mathrm{~nm}$ using a Polychrome IV monochromator (TILL Photonics). After correction for the individual background fluorescence signals, the ratio of the fluorescence at both excitation wavelengths $\left(F_{350} / F_{380}\right)$ was monitored. The extracellular solution used in ratiometric $\left[\mathrm{Ca}^{2+}\right]_{\mathrm{i}}$ measurements contained (in $\mathrm{mM}$ ) $140 \mathrm{NaCl}, 4 \mathrm{KCl}, 2 \mathrm{CaCl}_{2}, 1 \mathrm{MgCl}_{2}$, 5 glucose, and 10 HEPES, pH 7.4.

\section{Data analysis}

Electrophysiological data were analyzed using the WinASCD software (G. Droogmans, Leuven, Belgium). Pooled data were given as mean \pm SEM of $n$ cells.
Significance was tested using Student's paired $t$ test $(p<$ 0.05). The Kolmogorov-Smirnov test was used to determine statistical differences between probability distributions, and $p<0.01$ was considered statistically significant.

\section{Results}

Desensitization of TRPA1 during activation by agonists

TRPA1 channels in CHO cells were constitutively open without any stimulation and exhibited characteristic inactivation at positive potentials (Fig. 1a). Another typical feature of whole-cell TRPA1 currents was the rapid current decay after stimulation with MO (Fig. 1a,d, and data not shown). We first examined whether diC8-PI $(4,5) \mathrm{P}_{2}$ (referred to as $\mathrm{PIP}_{2}$ in the further text) could interfere with this desensitization. When activated by $200 \mu \mathrm{M}$ MO, currents through TRPA1 decreased with a time constant of $33 \pm 5 \mathrm{~s}$ $(n=6)$ at $-100 \mathrm{mV}$. Because TRPA1 currents inactivated at positive potentials, we restricted our analysis on inward currents at $-100 \mathrm{mV}$ and did not consider other properties such as rectification. When $15 \mu \mathrm{M} \mathrm{PIP}{ }_{2}$ was included in the patch pipette, desensitization of the MO-activated currents through TRPA1 was significantly diminished, and the time constant amounted to $92 \pm 12 \mathrm{~s}(n=5 ; p<0.05$; Fig. $1 \mathrm{~b}$,d). In addition, both the basal and the maximal MO-activated currents were slightly but significantly increased by intracellular application of $\mathrm{PIP}_{2}$ (Fig. 1e,f).

Wortmannin, an inhibitor of phosphatidylionsitol-4kinase (PI-4-K), retards the replenishment of $\mathrm{PIP}_{2}$, which results in depletion of the intracellular $\mathrm{PIP}_{2}$ pool [39]. In the whole-cell mode, preincubation of the TRPA1-expressing $\mathrm{CHO}$ cells with $50 \mu \mathrm{M}$ wortmannin for 15 min reduced both the constitutive and MO-activated currents (Fig. 1c-f). No effects could be observed when $1 \mu \mathrm{M}$ wortmannin was used, a concentration which should still block phosphatidylinositol-3-kinase (PI-3-K) [59] but not PI-4-K ( $n=3$, data not shown).

The aminosteroid derivative U73122 inhibits PLC activity $[6,52]$ and thereby prevents $\mathrm{PIP}_{2}$ hydrolysis. As such, U73122 strongly attenuated the desensitization after activation of TRPM4 by intracellular $\mathrm{Ca}^{2+}[40]$. We found that application of $1 \mu \mathrm{M}$ U73122 activated TRPA1, whereas the inactive analogue U73343 had no effect (Fig. 2a-c). Although this result would be in line with a

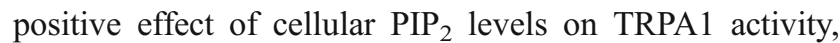
some caution is warranted. U73122 is an electrophilic compound and might thus act on TRPA1 through covalent linking with channel cysteines. In line herewith, application of the cysteine-reactive agonist $\mathrm{MO}$ was ineffective following treatment with $1 \mu \mathrm{M}$ U73122. Similar results have been previously found using $\mathrm{Ca}^{2+}$ imaging [3]. It 


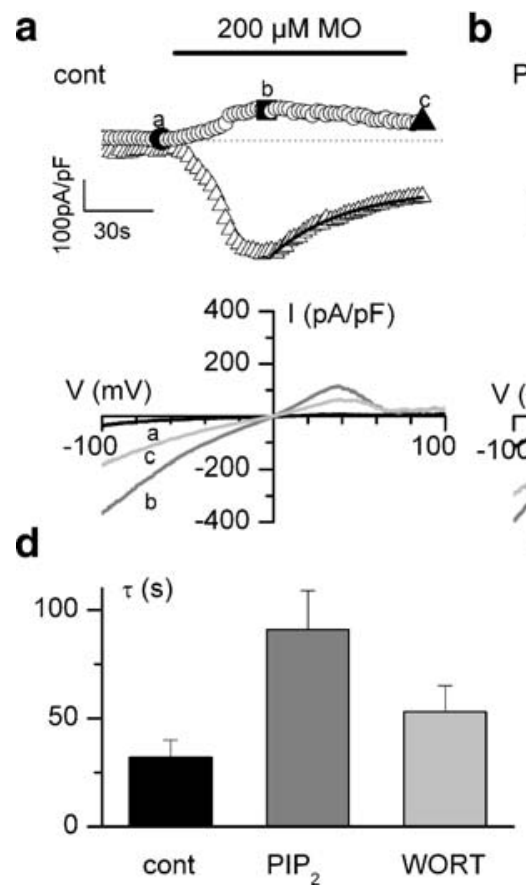

Fig. 1 Effects of $\mathrm{PIP}_{2}$ and wortmannin on whole-cell currents through TRPA1. a Time course of the whole-cell currents trough TRPA1 measured at $+40 \mathrm{mV}$ (open circles) and $-100 \mathrm{mV}$ (triangles). Bars indicate application of $200 \mu \mathrm{M}$ MO. Note the current activation and the decay of the current during MO application. This decay was fitted to a monoexponential function to obtain the time constant for desensitization. As seen in the voltage ramps traces, currents decay at positive potentials indicates inactivation of TRPA1. Same calibration for a-c. b Same protocol as in (a). The patch pipette contains $15 \mu \mathrm{M}$ diC8-PIP 2 . Note that TRPA1 was constitutively activated before application of $200 \mu \mathrm{M}$ MO. Decay of the current was slower than in the absence of $\mathrm{PIP}_{2}$ (monoexponential fit included). Current

should also be noted that U73343 lacks the electrophilic double bound that is predicted to be responsible for the cysteine reactivity of U73122.

Another widely used tool to modulate the $\mathrm{PIP}_{2}$ content of the plasma membrane is phenylarsine oxide (PAO),
C
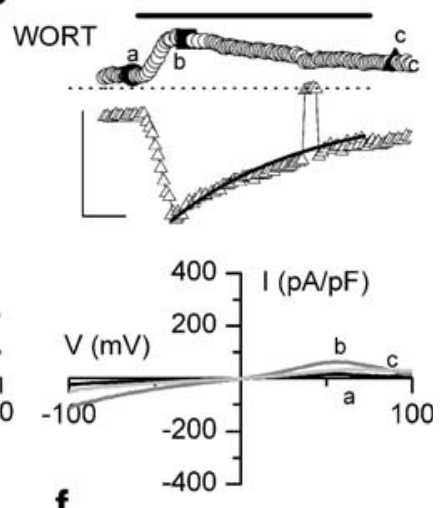

f

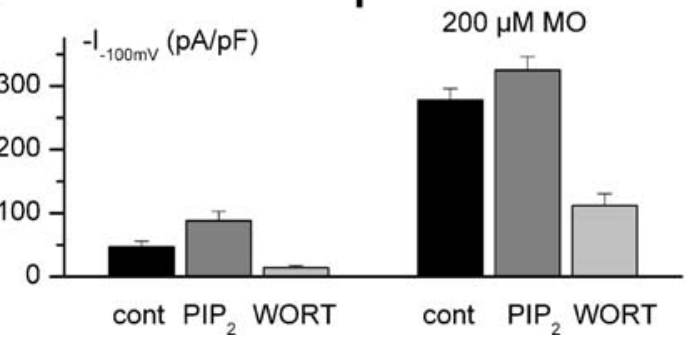

traces (panel below the time course) showed again inactivation which was shifted towards more positive potentials. c Same protocols as in (a). Cells were preincubated with $50 \mu \mathrm{M}$ wortmannin for $15 \mathrm{~min}$. d Averaged values for the time constant of desensitization obtained from monoexponential fit as shown in a-c. $\mathrm{PIP}_{2}$ significantly delayed desensitization $(p<0.01, n=5)$. e Current densities of constitutive open TRPA 1 channels before application of MO. Currents were measured at $-100 \mathrm{mV}$. $\mathrm{PIP}_{2}$ increased and wortmannin decreased this current significantly. f Current density measured at peak during MO application. No significant differences were obtained between controls and $\mathrm{PIP}_{2}$-loaded cells. Wortmannin highly significantly decreased the MO-activated current $(n=8, p<0.01)$. Same ordinate as in (e)

which inhibits PI-4-K and decreases PIP $_{2}$ synthesis $[22,61$, 64]. We found that application of $1 \mu \mathrm{M}$ PAO induced robust activation of TRPA1 (Supplementary Fig. 1). Also here, these effects of PAO should be interpreted with caution, since PAO has been shown to inhibit tyrosine

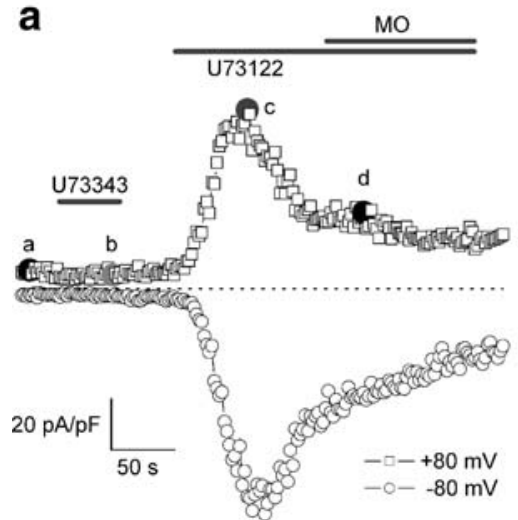

Fig. 2 Effects of the PLC inhibitor U73122 on whole-cell currents through TRPA1. a Time course of the whole-cell currents activated by U73122 measured at $+80 \mathrm{mV}$ (open squares) and $-80 \mathrm{mV}$ (open circles). A $500-\mathrm{ms}$ voltage ramp protocol from -150 to $+150 \mathrm{mV}$ was
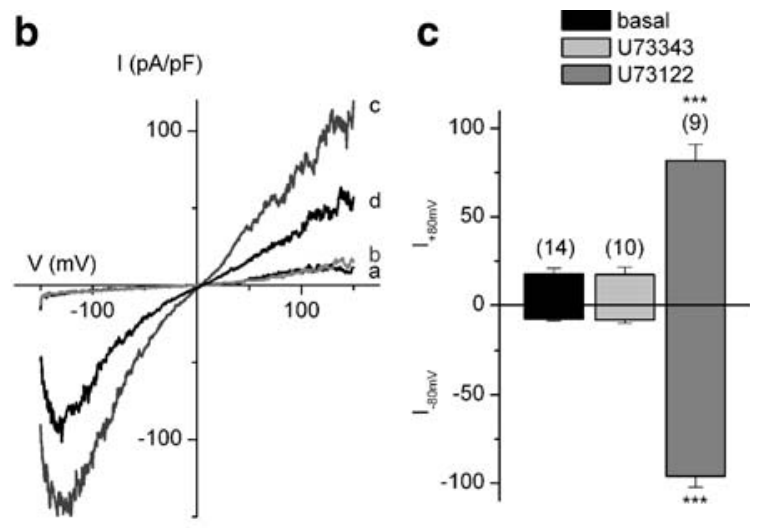

applied continuously every $2 \mathrm{~s}$. The membrane potential was held at $0 \mathrm{mV}$ between sweeps. b Current-voltage $(I-V)$ relations measured at the times indicated in (a). $\mathbf{c}$ Pooled data of the maximal currents at -80 and $+80 \mathrm{mV}$. Activation by $\mathrm{U} 73122$ is highly significant $(p<0.01)$ 
phosphatase activity by modifying cysteine residues at the active site of the enzyme $[13,15,51]$ and preferentially reacts with vicinal cysteine residues to form stable ring structures [60]. Following PAO treatment, MO was ineffective to further stimulate TRPA1 (data not shown, $n=5$ ). Being a cysteine-reactive agent, PAO appears not to be a usable tool for studying PIP ${ }_{2}$ effects on TRPA1.

Neomycin, a positively charged aminoglycoside antibiotic, binds the negatively charged head group of $\mathrm{PIP}_{2}$ and thereby masks its effect $[12,25,45]$. To examine the effects of neomycin on TRPA1, we dialyzed cells with $10 \mu \mathrm{M} \mathrm{Ca}^{2+}$ via the pipette, which resulted in stable currents for $\sim 6 \mathrm{~min}$ followed by slow desensitization (data not shown, $n=12$ ) and allowed a direct comparison of the effects of neomycin on current decay. Inclusion of 1 or $5 \mathrm{mM}$ neomycin in the patch pipette resulted in a much faster decay of the $\mathrm{Ca}^{2+}$-activated TRPA1 current (Fig. 3a-c), which can be appreciated by the faster time constants of current decay and the significantly
Fig. 3 Effects of neomycin on whole-cell currents through TRPA1. a Representative time course of whole-cell currents elicited by $10 \mu \mathrm{M} \mathrm{Ca}^{2+}$ with or without neomycin via the patch pipette, and by $20 \mu \mathrm{M}$ MO.

Shown are the currents obtained from voltage ramps at $-80 \mathrm{mV}$ (lower trace) and $+80 \mathrm{mV}$ (upper trace), respectively. b Averaged time course of whole-cell currents at $+80 \mathrm{mV}$ activated by $10 \mu \mathrm{M} \mathrm{Ca}^{2+}$ via the patch pipette with and without neomycin. Dotted lines show the standard deviation. c $I-V$ relations obtained at the indicated time shown in (a). d $I-V$ relations activated by $20 \mu \mathrm{M}$ MO shown in (a). e Average values for current density at +80 and $-80 \mathrm{mV}$ at 0 and $300 \mathrm{~s}$ after break in. f Average values for MO-activated current density. g Time constant of current desensitization of the current at $+80 \mathrm{mV}$ obtained from monoexponential fitting. Error bars indicate SEM $(n>3 ; * p<0.05$; $* * p<0.01 ; * * * p<0.001)$ a

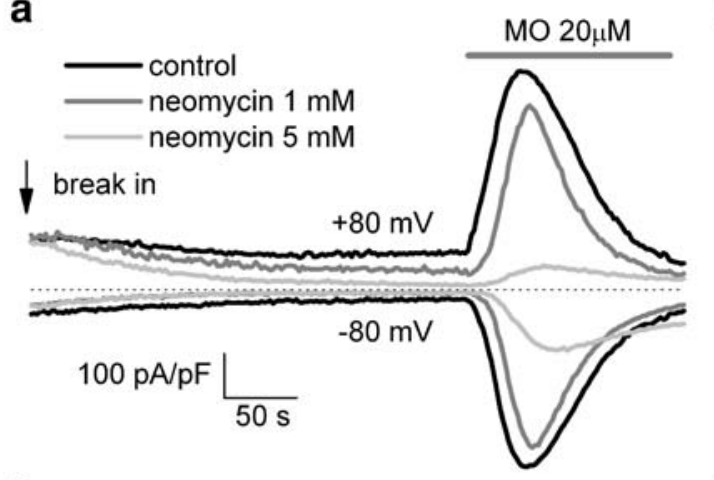

c

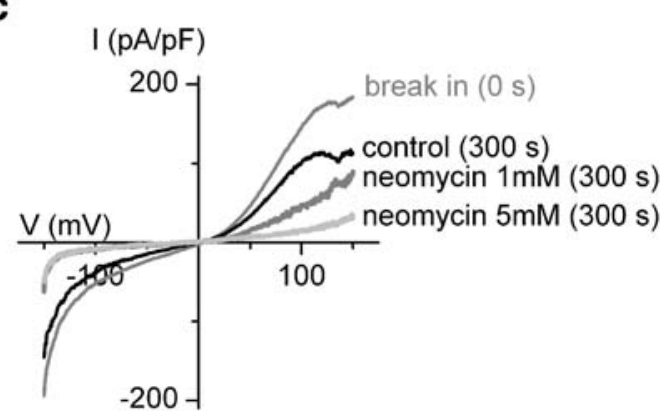

e

$(\mathrm{pA} / \mathrm{pF})$

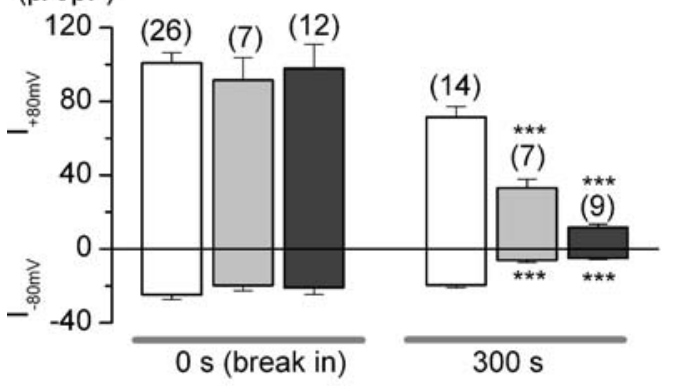

g

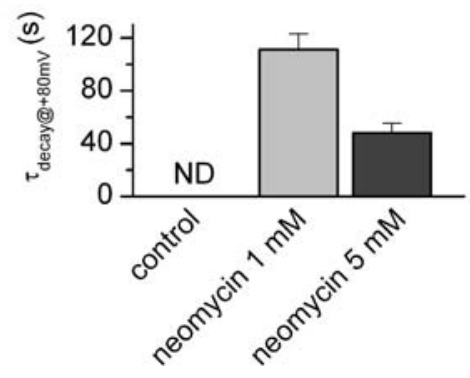

b

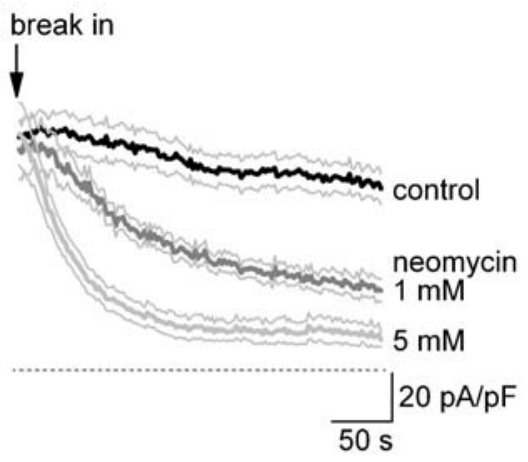

d

$\mathrm{I}(\mathrm{pA} / \mathrm{pF})$

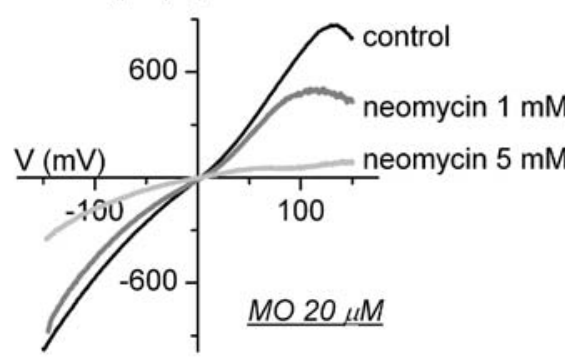

f

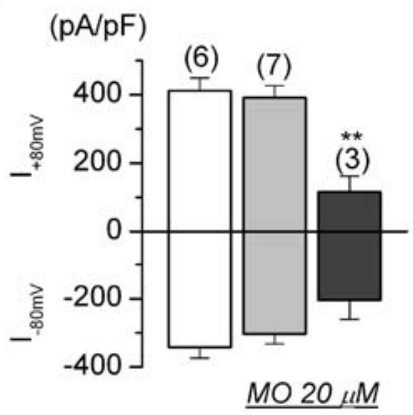


reduced residual current after $300 \mathrm{~s}$ (Fig. 3e,g). Moreover, the current response to $20 \mu \mathrm{M}$ MO was significantly reduced in cells dialyzed with $5 \mathrm{mM}$ neomycin (Fig. 3a,d, and f). When we used neomycin in inside-out patches (Fig. 4), we observed a very fast block and unblock $(n=3)$. In addition, the block by neomycin from the intracellular side was pronounced at positive potentials and weakened at negative potentials (data not shown, $n=3$ ). All these effects may indicate a "shielding" effect of the negative charges of $\mathrm{PIP}_{2}$ by neomycin in agreement to the direct binding to $\mathrm{PIP}_{2}$ [12] and explain the fast block and unblock which is also in agreement also with the whole-cell data. However, a direct block of TRPA1 cannot be excluded.

It has been recently shown that $\mathrm{KCNQ} \mathrm{K}^{+}$channels (Kv7), which require $\mathrm{PIP}_{2}$ binding for activation, are suppressed by high intracellular $\mathrm{Mg}^{2+}$ concentrations,
Fig. 4 Effects of neomycin on single channel currents through TRPA1. a Spontaneous activity from an inside-out patch measured at $+60 \mathrm{mV}$. Application of $1 \mathrm{mM}$ neomycin to the inner side immediately inhibited channel activity (b) and (c) shows amplitude histograms from the same cell as shown in (a). The single channel conductance is $\sim 102 \mathrm{pS}$. d Block by neomycin is fast and channel activity reappears immediately after washing out of neomycin. This fast recovery is in complete contrast with a $\mathrm{PIP}_{2}$ scavenger. e Single channel traces in a higher time resolution from the trace shown in (d)

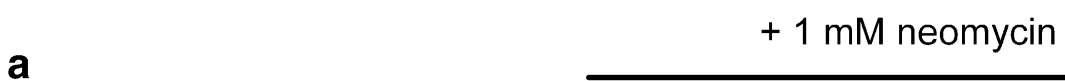

a

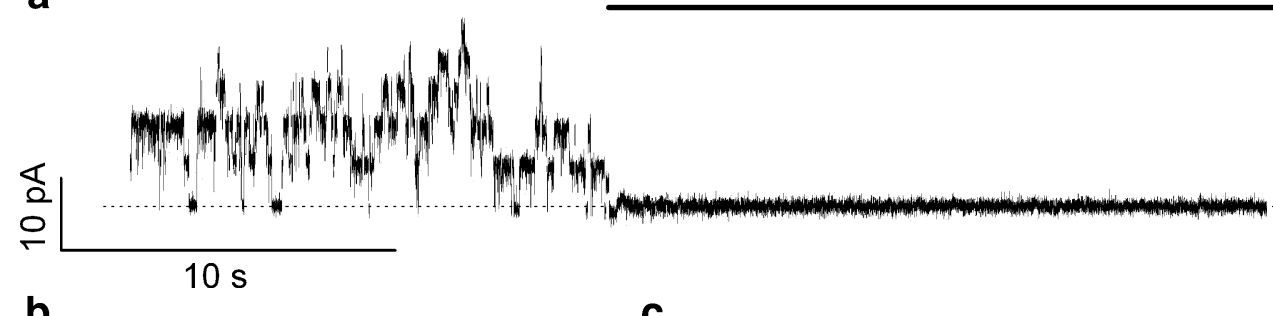

b

C
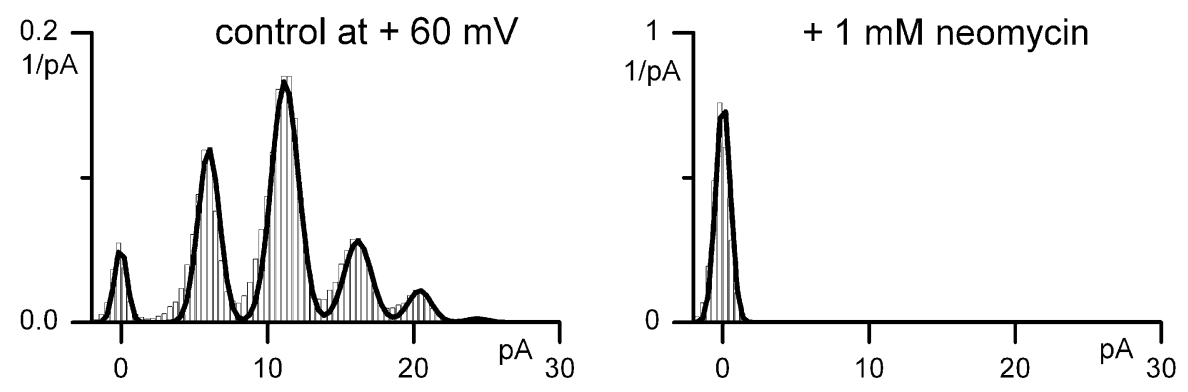

d

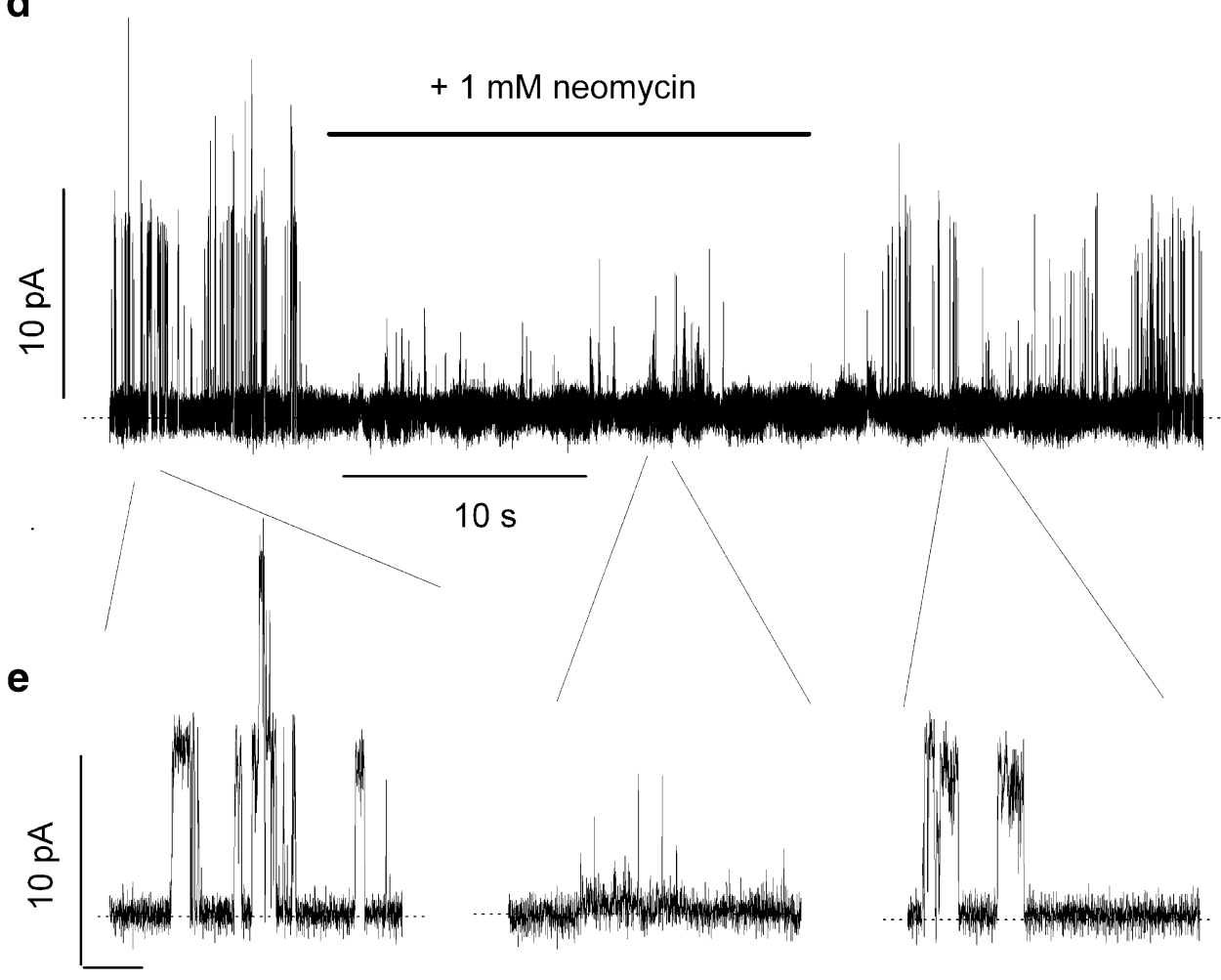

$0.1 \mathrm{~s}$ 
which is attributed to electrostatic binding of this cation to $\mathrm{PIP}_{2}$ and thereby reducing its free amount [57]. We found that application of $10 \mathrm{mM} \mathrm{Mg}^{2+}$ through the patch pipette caused a strong decline of the basal current activity $(18 \pm$ $4 \%$ of the initial current density at $+80 \mathrm{mV}$ and $28 \pm 7 \%$ at $-80 \mathrm{mV}$ after $5 \mathrm{~min} ; n=4$ ), but did not prevent the response to MO (Fig. 5a,b). In contrast, buffering intracellular divalents with $10 \mathrm{mM}$ EDTA in the pipette caused a clear run up of TRPA1 channel activity $(244 \pm 45 \%$ at $+80 \mathrm{mV}$, $p=0.034$, and $279 \pm 50 \%$ at $-80 \mathrm{mV}, p=0.0016$ after $5 \mathrm{~min}$; $n=3$ ) but left the MO response unaltered (Fig. $5 \mathrm{c}-\mathrm{e}$, MO response in $10 \mathrm{mM} \mathrm{Mg}{ }^{2+}: 375 \pm 12 \mathrm{pA} / \mathrm{pF}$ at $+80 \mathrm{mV}$, $-260 \pm 17 \mathrm{pA} / \mathrm{pF}$ at $-80 \mathrm{mV}$, and in $10 \mathrm{mM}$ EDTA: $313 \pm$ $76 \mathrm{pA} / \mathrm{pF}$ at $+80 \mathrm{mV}$ and $-215 \pm 20 \mathrm{pA} / \mathrm{pF}$ at $-80 \mathrm{mV}, p>$ $0.05, n=3$ ). These whole-cell data are supported by inside-out experiments. After excision, channel activity was immediately blocked after application of $10 \mathrm{mM} \mathrm{Mg}^{2+}$ to the inner side of the excised patch and partially recovered after washing out of $\mathrm{Mg}^{2+}(n=5$, see Supplementary Fig. 2 for an example including statistics). In conclusion, all measured $\mathrm{Mg}^{2+}$ effects support the hypothesis that electrostatic binding of $\mathrm{Mg}^{2+}$ to $\mathrm{PIP}_{2}$ is involved in TRPA1 modulation.
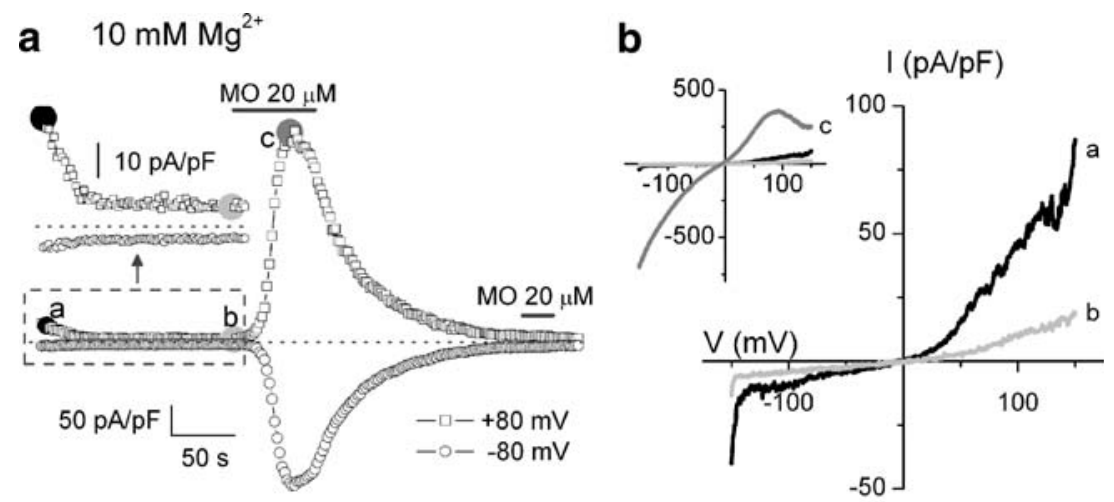

C $10 \mathrm{mM}$ EDTA

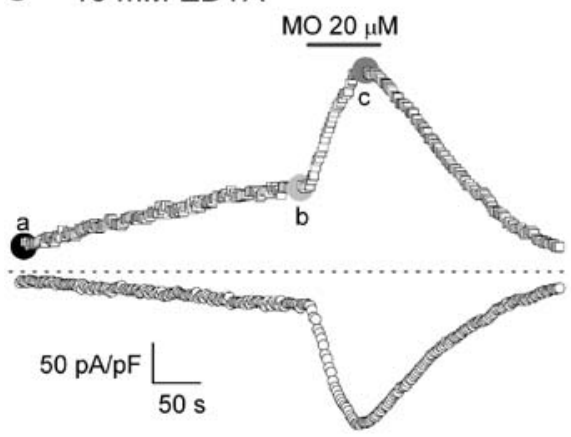

d
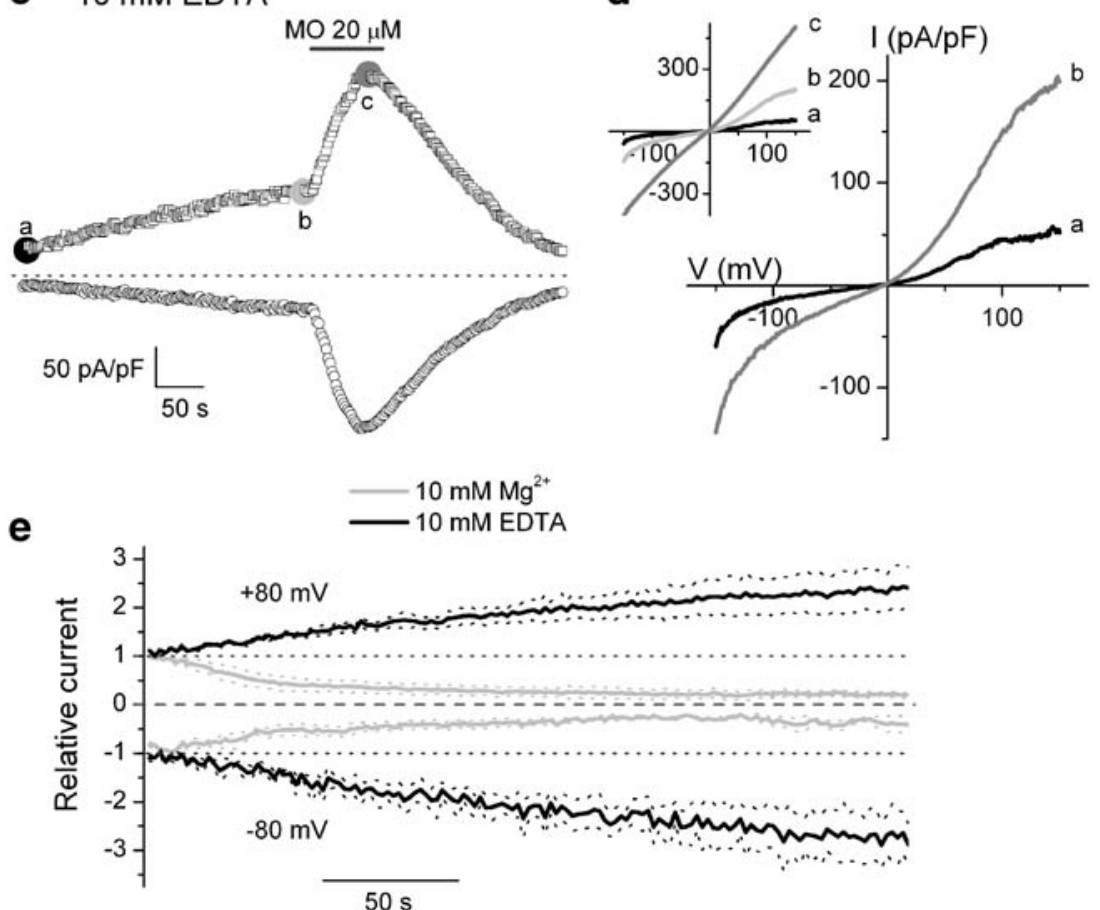

Fig. 5 Effects of $\mathrm{Mg}^{2+}$ and EDTA on whole-cell currents through TRPA1. a Time course of whole-cell currents with $10 \mathrm{mM} \mathrm{Mg}^{2+}$ via the patch pipette at $+80 \mathrm{mV}$ (open squares) and $-80 \mathrm{mV}$ (open circles) elicited by $10 \mu \mathrm{M} \mathrm{Ca}^{2+}$ and by $20 \mu \mathrm{M}$ MO. b $I-V$ relations obtained at the indicated time shown in (a). c Time course of whole-cell currents with $10 \mathrm{mM}$ EDTA via the patch pipette elicited by $10 \mu \mathrm{M} \mathrm{Ca}^{2+}$ and by $20 \mu \mathrm{M}$ MO. d $I-V$ relations obtained at the indicated time shown in (c). See text for statistical analysis. e Averaged time course of wholecell currents at +80 and $-80 \mathrm{mV}$ with $10 \mathrm{mM} \mathrm{Mg}^{2+}$ or $10 \mathrm{mM}$ EDTA in the pipette. Currents were normalized to the currents obtained at the beginning of the whole-cell configuration. Dotted lines show the standard deviation 
Run down of currents through TRPA1 in inside-out patches

In cell-attached patches, single TRPA1 channels recapitulated the properties of the whole-cell currents: constitutive current activity was obvious in the absence of an activating stimulus, and extracellular application of MO evoked a strong increase in channel activity followed by a rapid current decay (Supplementary Fig. 3).

In line with previous reports [23, 38], TRPA1 currents in inside-out patches decayed to a quasi zero steady-state level (Fig. 6a). However, the time it takes for channel activity to completely disappear varies between patches and ranges from seconds to minutes. Application of $15 \mu \mathrm{M} \mathrm{PIP}{ }_{2}$ to the inner side of an excised patch induced recovery of channel activity (Fig. 6a). Moreover, when $15 \mu \mathrm{M} \mathrm{PIP}{ }_{2}$ was present in the bath solution prior to patch excision, desensitization was no longer observed. This behavior could also be seen using voltage ramps. Averaged single channel currents from cell-attached patches without any stimulation nicely mimicked the features of whole-cell current, i.e., nearly linear current at negative potentials and inactivation at positive potentials (Fig. 6b). From five experiments as shown in Fig. 6a, we obtained an open probability $\left(P_{\text {open }}\right)$ value at
$-60 \mathrm{mV}$ of $0.39 \pm 0.07$ before excision. Channel activity decreased in inside-out patches to a $P_{\text {open }}<0.01$. Application of $\mathrm{PIP}_{2}$ to the inner side of the excised patches led to current recovery and a $P_{\text {open }}$ of $0.36 \pm 0.06$. Similar results were obtained using ramp protocols (Fig. 6b-d). After virtually complete run down of the current, application of $\mathrm{PIP}_{2}$ leads to a reactivation of channel activity. At $+80 \mathrm{mV}$, the average current amplitude of the TRPA1 current after $\mathrm{PIP}_{2}$ application amounted to $118 \pm 34 \%(n=6)$ of the current amplitude before excision.

We also examined the effect of Mg-ATP, which is known to activate PI-4-K leading to regeneration of $\mathrm{PIP}_{2}$ from phosphatidylinositol(4)phosphate (PI(4)P) $[2,16]$. Application of $2 \mathrm{mM} \mathrm{Mg}$-ATP to inside-out patches in which TRPA1 channel activity had run down resulted in the reappearance of channel activity (Fig. 7a). In this set of experiments, $P_{\text {open }}$ at $-60 \mathrm{mV}$ changed from $0.39 \pm 0.11$ before excision to $<0.01$ after excision and to $0.49 \pm 0.15$ upon application of $2 \mathrm{mM} \mathrm{Mg-ATP}(n=5)$. Similar results were obtained when the ramp protocol was used. In cell-attached patches, currents through TRPA1 were constitutively present and displayed characteristic voltagedependent inactivation at positive potentials (Fig. 7b). After
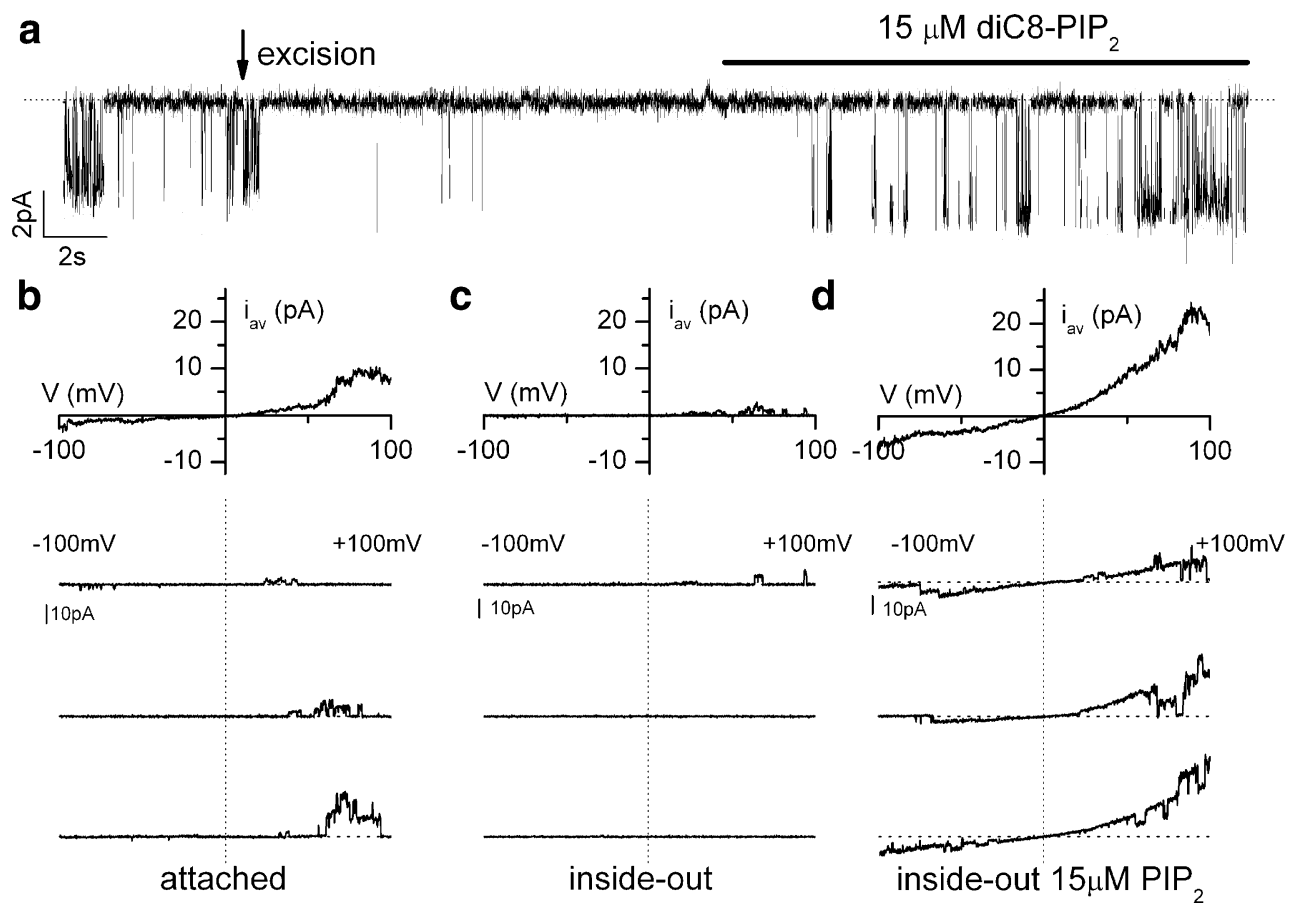

Fig. $6 \mathrm{PIP}_{2}$ modulates TRPA1 activity in inside-out patches. a Single channel currents measured first in cell-attached patches at $-60 \mathrm{mV}$ (pipette $5 \mathrm{mM} \mathrm{Mg}^{2+}, 0 \mathrm{Ca}^{2+}$ ). The arrow indicates the time of excision. No ATP was present at the inner side of the inside-out patch. Note the fast disappearance (run down) of single channel activity. Activity in the excised patch completely disappeared. After application of $15 \mu \mathrm{M}$ diC8-PIP 2 channel activity reappeared. b Ensembleaveraged current from voltage ramps obtained from a cell-attached patch (38 sweeps averaged). Note the activity of constitutive open

channels. Three consecutive individual traces are shown below the averaged. c Same cell as in (b). The patch was now excised. The ensemble-averaged current was almost zero (30 sweeps averaged). Individual traces (below) obtained after patch decision showed nearly no activity. d Same cell as in (b), however, $15 \mu \mathrm{M} \mathrm{PIP}_{2}$ was added at the inner side of the patch. Note the increase in the averaged current (from 45 sweeps) and the activity of the individual channels shown in the current traces below the average current 


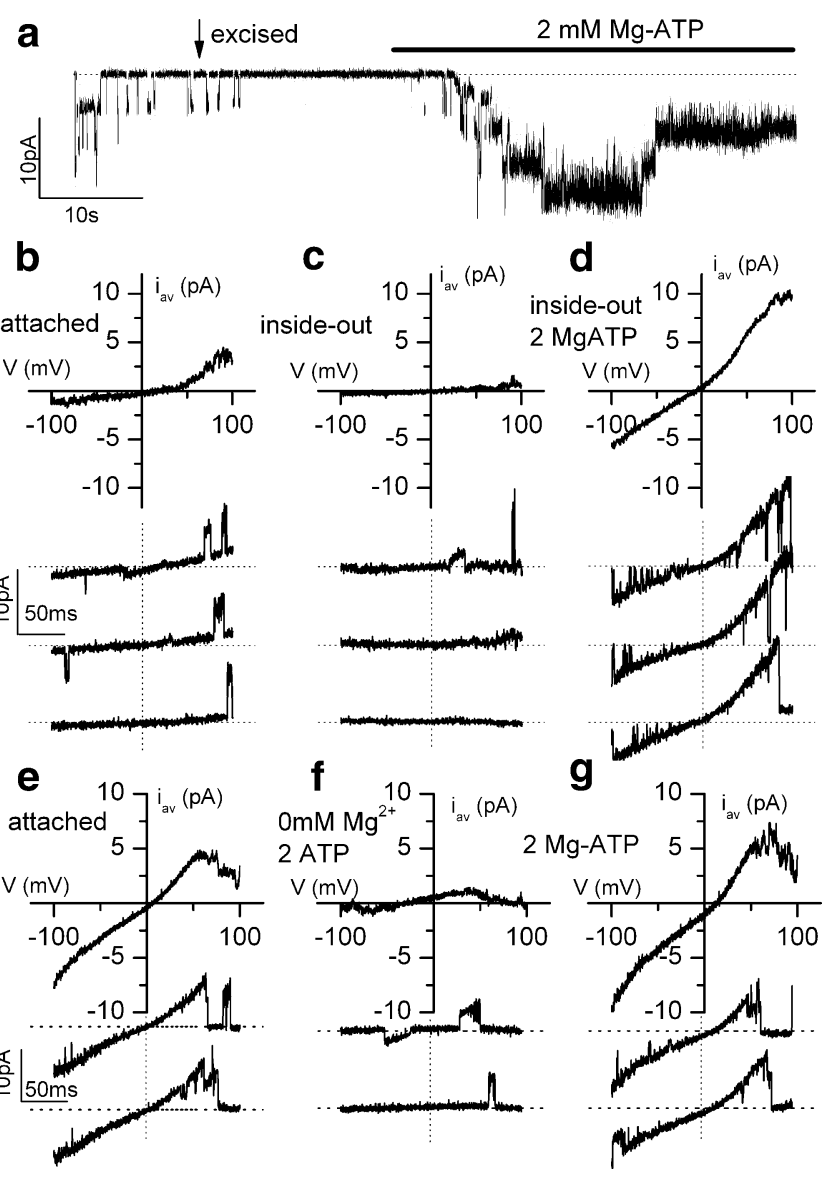

Fig. $7 \mathrm{Mg}$-ATP rescues single channel activity in inside-out patches. a Single channel currents were first measured in cell-attached patches at $-60 \mathrm{mV}$ (pipette $5 \mathrm{mM} \mathrm{Mg}{ }^{2+}, 0 \mathrm{Ca}^{2+}$ ). This patch had a high constitutive activity. The arrow indicates the time of excision. No ATP or $\mathrm{Mg}^{2+}$ was present at the inner side of the inside-out patch. Note the fast disappearance (run down of single channel activity). At the time indicated by the bar, $2 \mathrm{mM}$ Mg-ATP was added and channel activity was rescued. b Averaged mean current obtained from a cell-attached patch (from 30 sweeps). Single consecutive traces are depicted below the average current. c Same patch as in (b) but after excision. As single traces, the first three consecutive sweeps after excision are shown. Ensemble-averaged current (top) is from 17 sweeps. d Same cell as in (b). The inside-out patch faced on its internal side $15 \mu \mathrm{M}$ $\mathrm{PIP}_{2}$. Single traces in the presence of $2 \mathrm{mM}$ ATP are shown below the averaged current (from 32 sweeps). Note the dramatic increase in channel activity. e Averaged current from 12 sweeps in the cell-attached mode. Two selected traces are shown below the ensemble-averaged current. f Averaged mean current from ten sweeps the cell-attached patch in (e) after excision. Activity run nearly completely down and application of $2 \mathrm{mM}$ ATP without $\mathrm{Mg}^{2+}$ did not reactivate the current. Single channel traces from the first two sweeps are shown below the averaged current. Note the lack of TRPA1 activation. g Averaged mean current (from 15 sweeps) obtained from the same inside-out patch as shown in (e) after application of $2 \mathrm{mM}$ Mg-ATP. Note the substantial increase in TRPA1 activity. Single channel traces from this patch are shown below the averaged current. The dotted lines always indicate zero current and $0 \mathrm{mV}$

excision, channel activity disappeared almost completely (Fig. 7c), but subsequent application of Mg-ATP restored current activity (Fig. 7d, 167 $\pm 19 \%$ of current amplitude before excision at $+80 \mathrm{mV}, n=7$ ). Moreover, when patches were excised in an intracellular solution containing $2 \mathrm{mM}$ Mg-ATP, the current run down was prevented (data not shown). Importantly, Mg-free ATP was much less potent in restoring channel activity after run down than Mg-ATP (Fig. 7e-g). Ensemble-averaged currents obtained from ramp protocols as shown in Fig. 7 decreased after excision and in the presence of $2 \mathrm{mM}$ ATP to $9 \pm 3 \%$ of the value obtained from the cell-attached mode but increased in the same patch after reapplication of $2 \mathrm{mM} \mathrm{Mg-ATP}$ to $119 \pm 7 \%$ $(n=3)$. These findings speak against a direct binding of ATP to the channel and are in line with the notion that $\mathrm{Mg}$ ATP reverses the decay of TRPA1 activity by restoring the $\mathrm{PIP}_{2}$ levels in the membrane patch. Consequently, these results may also indicate that PI-4-K activity remains preserved in TRPA1-containing inside-out patches.

The effects of $\mathrm{PIP}_{2}$ and Mg-ATP were different from what we have described previously for TRPM4 [40]. For example, if the channel activity completely ceased for more than $2 \mathrm{~min}$, we could not recover the current by any measure. If patches were excised in $15 \mu \mathrm{M} \mathrm{PIP}{ }_{2}$ or $2 \mathrm{mM}$ Mg-ATP containing solution, run down to zero activity was prevented ( $n=4$, and $n=12$, respectively). Similarly, if we excised the patches in $1 \mathrm{mM}$ inorganic triphosphate [23], channel activity could be preserved. However, when after patch excision channel activity ceased for more than $2 \mathrm{~min}$, $\mathrm{PPP}_{\mathrm{i}}$ or MO could also not reactivate the channel $(n=7$, data not shown). However, as long as some residual activity in excised patches was observed, this activity could be increased by MO (see Supplementary Fig. 4).

Surprisingly, application of poly-L-lysine (PLL), a positively charged macromolecule that acts as a scavenger of $\mathrm{PIP}_{2}$ analogous to neomycin [29, 62], to inside-out patches activated rather than inhibited currents through TRPA1 (Supplementary Fig. 5). This activation occurred at concentrations that rapidly and completely abolished TRPM4 currents $(5 \mu \mathrm{g} / \mathrm{ml})$ [40]. Although we have no explanation for this effect of PLL, we consider it unlikely that this compound activates TRPA1 by removing tonic block by $\mathrm{PIP}_{2}$, given the opposite effects of neomycin and $\mathrm{Mg}^{2+}$.

\section{Effects of wortmannin in TG neurons}

Finally, we examined whether interference with $\mathrm{PIP}_{2}$ metabolism affects native TRPA1 in sensory neurons. In isolated mouse TG neurons, approximately $30 \%$ of the cells displayed a robust increase in intracellular $\mathrm{Ca}^{2+}$ upon stimulation with $25 \mu \mathrm{M}$ MO. In neurons pretreated with $50 \mu \mathrm{M}$ wortmannin for $20 \mathrm{~min}$, the $\mathrm{MO}$-induced $\mathrm{Ca}^{2+}$ transient decayed much faster than in the non-treated control group (Fig. 8a). Four minutes after washing out of $\mathrm{MO},\left[\mathrm{Ca}^{2+}\right]_{\mathrm{i}}$ decreased to $61 \pm 9 \%$ of the peak value under control conditions $(n=11)$ and to $5 \pm 3 \%(n=7)$ after 

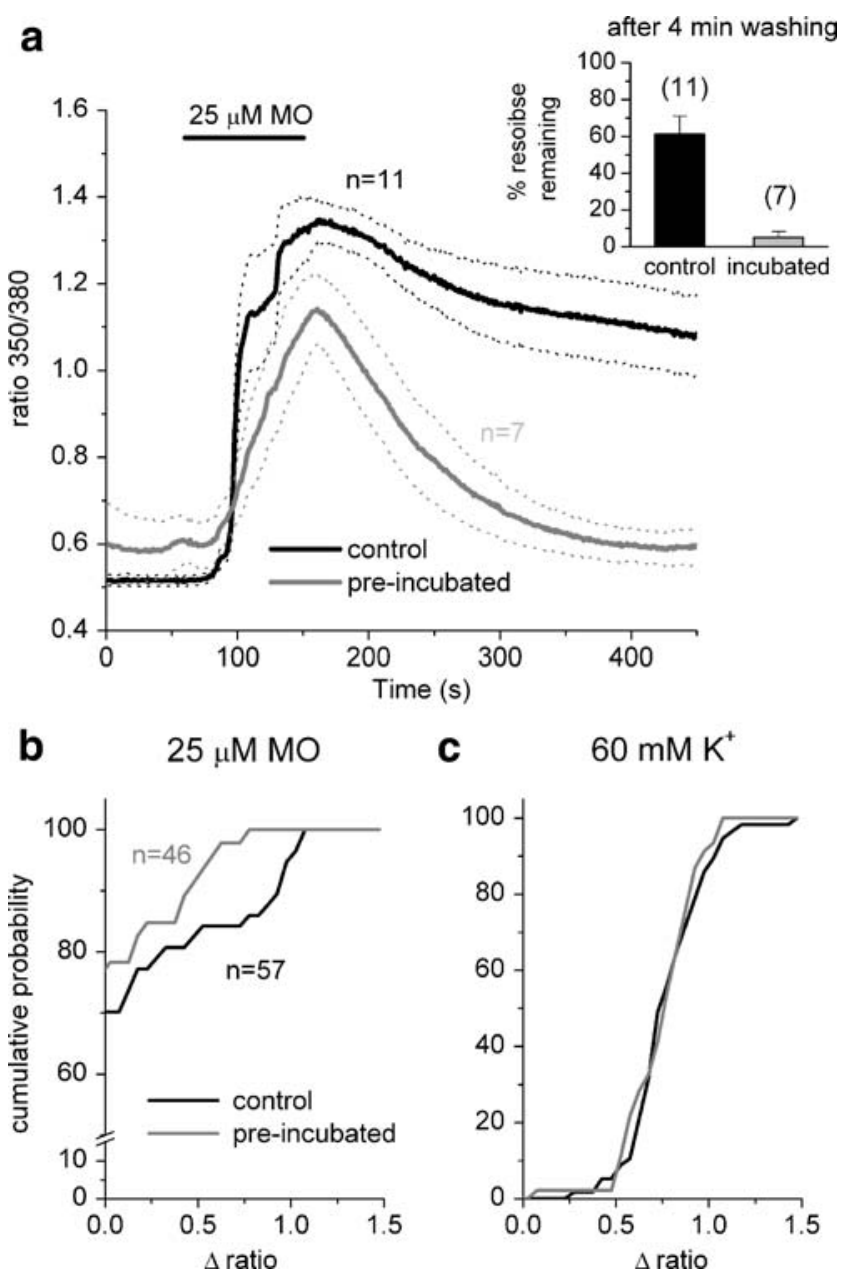

Fig. 8 Effects of MO on intracellular $\mathrm{Ca}^{2+}$ of isolated TG neurons in control cells and cells preincubated with wortmannin. a Application of $25 \mu \mathrm{M}$ MO induced a fast and slowly decaying $\mathrm{Ca}^{2+}$ transient $(n=11$, black trace, mean values \pm SEM). Preincubation with $50 \mu \mathrm{M}$ wortmannin for $20 \mathrm{~min}$ dramatically accelerated $\mathrm{Ca}^{2+}$ decay (gray trace, mean value $\pm \mathrm{SEM})$. The inset shows the statistics on all cells: 4 min after washing out of $\mathrm{MO},\left[\mathrm{Ca}^{2+}\right]_{\mathrm{i}}$ decreased to $61 \pm 9 \%$ of the peak value under control conditions $(n=11)$ and to $5 \pm 3 \%(n=7)$ after preincubation with wortmannin. b Cumulative probabilities of the MO induced changes in fluorescence ratio. Preincubation with wortmannin increased the fraction of neurons, which did not respond to MO and reached probability 1 at much smaller ratios as compared with the neurons with no preincubation (data from 57 cells). The KolmogorovSmirnov test was used to determine statistical differences between probability distributions $(p<0.01)$. c Same analysis as in $(\mathbf{b})$, however, cells were stimulated by $60 \mathrm{mM} \mathrm{K}^{+}$. No difference between non- and preincubated cells $(n=46)$

preincubation with wortmannin (Fig. 8a inset). In addition, the average increase in intracellular $\mathrm{Ca}^{2+}$ was significantly smaller in the wortmannin-treated cells. In order to quantify the distribution of the $\mathrm{Ca}^{2+}$ peaks in individual cells, we determined the probability density function of the fluorescence ratios ( $X$ axis). Normalizations to their respective maximum values are shown in Fig. $8 \mathrm{~b}$ and indicate that wortmannin-pretreated neurons have significantly smaller $\mathrm{Ca}^{2+}$ transients. However, the $\mathrm{Ca}^{2+}$ response to a depolariz- ing stimulus was unchanged by wortmannin, excluding a non-specific effect on $\mathrm{Ca}^{2+}$ homeostasis in these cells (Fig. 8c).

\section{Discussion}

Phosphoinositides, and $\mathrm{PIP}_{2}$ in particular, regulate a plethora of ion channels including TRP channels (for reviews see $[8,14,26-28,46-49,56,63])$. The action of $\mathrm{PIP}_{2}$ on TRP channels is mainly stimulatory, as is clearly the case for TRPM4, TRPM5, TRPM7, TRPM8, and TRPV5 [26, 28, 40, 47, 49]. Also TRPV1 is probably activated by $\mathrm{PIP}_{2}$ [53]; however, this effect might depend on the concentration of the used agonist, e.g., capsaicin [30]. Clear inhibitory effects of PIP $_{2}$ have been reported for TRPC4 [42] and TRPP2 (PKD2) [31].

The situation is controversial for TRPA1. It has been recently shown that TRPA1 can be potentiated via the protease-activated receptor PAR2 [10]. Moreover, wholecell dialysis with either by application of PLL or a $\mathrm{PIP}_{2-}$ specific antibody, or activation of PLC using m-3M3FBS mimicked the effect of PAR2 activation, which led to the suggestion that the PAR2-mediated potentiation reflects a relief of TRPA1 from inhibition by $\mathrm{PIP}_{2}$ [10]. These data appear at variance with the main findings of our present study, which suggest activation rather than inhibition of TRPA1 by PIP 2 . However, in their report, a direct application of $\mathrm{PIP}_{2}$ to the channel in inside-out patches, which is the most direct approach to check channel modulation, has not been performed. It is also possible, that PIP $_{2}$ might have a dual effect on TRPA1 activity. For example, in the case of TRPV1, the capsaicin concentration determines whether $\mathrm{PIP}_{2}$ has an inhibitory or stimulatory action on channel activity [30].

Kim and Cavanaugh [23] have reported that $\mathrm{PIP}_{2}$ has no effect on channel activation in inside-out patches, whereas inorganic polyphosphates can reconstitute channel activity in excised patches. We could confirm these latter findings (see also Supplementary Fig. 2), but also see clear effects with $\mathrm{PIP}_{2}$. However, in comparison with its effects on other TRP channels, e.g., TRPM4 [40], the effects of $\mathrm{PIP}_{2}$ on TRPA1 were clearly less pronounced and were weaker. A possible action of $\mathrm{PIP}_{2}$ could resemble the poly-phosphate action on the TRPA1-N-terminus as described by Kim and Cavanaugh [23]. Unfortunately, this is difficult to test experimentally because deletion mutants of TRPA1 lacking one or more ankyrin repeat domains are not functional (Nilius and Prenen, unpublished).

A recent study on the mechanisms of TRPA1 desensitization has demonstrated that the depletion of $\mathrm{PIP}_{2}$ is responsible for the desensitized MO-activated TRPA1. Prolonged elevation in $\left[\mathrm{Ca}^{2+}\right]_{i}$ in sensory neurons induced 
by capsaicin triggers $\mathrm{PIP}_{2}$ depletion which, in turn, attenuates TRPA1 activity. This desensitization is prevented by application of $\mathrm{PIP}_{2}$ in the recording pipette in whole-cell measurements, which is in line with our data suggesting a positive regulation of $\mathrm{PIP}_{2}$ on the channel activity of TRPA1 [1].

In the present study, we demonstrate the direct effects of PIP $_{2}$ on TRPA1 in excised patches. In inside-out patches in which TRPA1 activity was diminished, PIP $_{2}$ was able to reactivate the channel. A similar effect was obtained using Mg-ATP, which we attribute to its ability to activate lipid kinases and thereby regenerate $\mathrm{PIP}_{2}$ from PI(4)P $[2,16,40$, $46,48,56]$. However, if the channel activity in inside-out patches had ceased for a prolonged period ( $>2 \mathrm{~min}$ ), we no longer observed channel reactivation using $\mathrm{PIP}_{2}, \mathrm{Mg}$-ATP, or $\mathrm{PPP}_{\mathrm{i}}$ [23], indicating that after a prolonged time of excision run down is irreversible. In whole-cell recordings, we found that $\mathrm{PIP}_{2}$ supplied via the patch pipette delayed the decay of TRPA1 current after stimulation with MO, whereas the $\mathrm{PIP}_{2}$ scavenger neomycin accelerated this current decay and diminished the $\mathrm{Ca}^{2+}$ - and MO-activated TRPA1 currents. Similar inhibitory effects were obtained when the $\mathrm{PIP}_{2}$ pool was reduced by treatment with the PI-4$\mathrm{K}$ inhibitor wortmannin or when intracellular $\mathrm{Mg}^{2+}$ or neomycin screened $\mathrm{PIP}_{2}$. On the other hand, inclusion of $10 \mathrm{mM}$ EDTA in the pipette, which chelates all intracellular free $\mathrm{Mg}^{2+}$, provoked an increase of the channel activity. These findings are reminiscent of the inhibitory action of $\mathrm{Mg}^{2+}$ on KCNQ K${ }^{+}$channels, which has been attributed to the electrostatic interaction between $\mathrm{Mg}^{2+}$ and the negatively charged moiety of $\mathrm{PIP}_{2}$, leading to loss of interaction between $\mathrm{PIP}_{2}$ and the KCNQ K${ }^{+}$channels [57]. In addition to the shielding effect of negative $\mathrm{PIP}_{2}$ charges by $\mathrm{Mg}^{2+}$, it may also serve as a co-factor for lipid phosphatases which would promote $\mathrm{PIP}_{2}$ depletion and might also explain the partial recovery of TRPA1 currents in excised patches after wash out of $\mathrm{Mg}^{2+}$ [18].

At present, we have no information about the regions of TRPA1 involved in the actions of $\mathrm{PIP}_{2}$. In other TRP channels, regions in the $\mathrm{C}$-terminus rich in basic residues have been implicated in the effects of $\mathrm{PIP}_{2}$ and may act as $\mathrm{PIP}_{2}$ interaction sites. Sequence analysis identified several clusters of positively charged residues in TRPA1 that could serve a similar role (Supplementary Fig. 6).

In conclusion, we have demonstrated that $\mathrm{PIP}_{2}$ has a positive modulatory effect on the cation channel TRPA1. However, when compared to the $\mathrm{PIP}_{2}$ modulation of another $\mathrm{Ca}^{2+}$-activated TRP channel TRPM4 [40], there were some clear differences. The $\mathrm{PIP}_{2}$ scavenger PLL activated TRPA1 (own data and see [10]), whereas it inhibited channel activity of TRPM4 and other TRP channels. However, intracellular $\mathrm{Mg}^{2+}$ and neomycin showed an inhibitory action on $\mathrm{Ca}^{2+}$-activated TRPA1 channel, in line with their known interaction with $\mathrm{PIP}_{2}$. Possibly, PLL acts directly on TRPA1 in a $\mathrm{PIP}_{2}$-independent manner. PIP 2 applied to excised patches had only a modest effect on channel activity, in contrast to the dramatic effects on TRPM4, which included a 100 -fold increase in $\mathrm{Ca}^{2+}$ sensitivity and an important leftward shift of the voltagedependent activation curve. Moreover, our data point out that several widely used tools to study the effects of $\mathrm{PIP}_{2}$ (PLL, PAO, U73122) are of only limited use in the case of TRPA1, as they have non-specific effects and/or activate the channel through covalent modification. However, taken together, our data indicate that TRPA1 activity depends on cellular PIP levels, providing a mechanism for regulation of the sensitivity of TRPA1-expressing (nociceptive) neurons.

Acknowledgments We thank Drs. A. Segal, R. Vennekens, K. Talavera, D. D'hoedt, N. Damann, and T. Shimizu for very helpful discussions and A. Janssens and M. Benoit for technical assistance. This work was supported by the Human Frontiers Science Programme (HFSP Research Grant Ref. RGP 32/2004), the Belgian Federal Government, the Flemish Government, the Onderzoeksraad KU Leuven (GOA 99/07, F.W.O. G.0214.99, F.W.O. G. 0136.00; F.W.O. G.0172.03, Interuniversity Poles of Attraction Program, Prime Ministers Office IUAP) and the Excellentiefinanciering (EF/95/010).

\section{References}

1. Akopian AN, Ruparel NB, Jeske NA, Hargreaves KM (2007) TRPA1 desensitization in sensory neurons is agonist-dependent and regulated by TRPV1-directed internalization. J Physiol 583:175-193

2. Balla T (2001) Pharmacology of phosphoinositides, regulators of multiple cellular functions. Curr Pharm Des 7:475-507

3. Bandell M, Story GM, Hwang SW, Viswanath V, Eid SR, Petrus MJ, Earley TJ, Patapoutian A (2004) Noxious cold ion channel TRPA1 is activated by pungent compounds and bradykinin. Neuron 41:849-57

4. Bang S, Kim KY, Yoo S, Kim YG, Hwang SW (2007) Transient receptor potential A1 mediates acetaldehyde-evoked pain sensation. Eur J Neurosci 26:2516-23

5. Bautista DM, Jordt SE, Nikai T, Tsuruda PR, Read AJ, Poblete J, Yamoah EN, Basbaum AI, Julius D (2006) TRPA1 mediates the inflammatory actions of environmental irritants and proalgesic agents. Cell 124:1269-82

6. Bleasdale JE, Thakur NR, Gremban RS, Bundy GL, Fitzpatrick FA, Smith RJ, Bunting S (1990) Selective inhibition of receptorcoupled phospholipase C-dependent processes in human platelets and polymorphonuclear neutrophils. J Pharmacol Exp Ther 255:756-768

7. Caterina MJ (2007) Chemical biology: sticky spices. Nature 445:491-492

8. Chuang HH, Prescott ED, Kong H, Shields S, Jordt SE, Basbaum AI, Chao MV, Julius D (2001) Bradykinin and nerve growth factor release the capsaicin receptor from PtdIns(4,5)P2-mediated inhibition. Nature 411:957-962

9. Corey DP, Garcia-Anoveros J, Holt JR, Kwan KY, Lin SY, Vollrath MA, Amalfitano A, Cheung EL, Derfler BH, Duggan A, Geleoc GS, Gray PA, Hoffman MP, Rehm HL, Tamasauskas D, 
Zhang DS (2004) TRPA1 is a candidate for the mechanosensitive transduction channel of vertebrate hair cells. Nature 432:723-730

10. Dai Y, Wang S, Tominaga M, Yamamoto S, Fukuoka T, Higashi T, Kobayashi K, Obata K, Yamanaka H, Noguchi K (2007) Sensitization of TRPA1 by PAR2 contributes to the sensation of inflammatory pain. J Clin Invest 117:1978-1987

11. Doerner JF, Gisselmann G, Hatt H, Wetzel CH (2007) Transient receptor potential channel A1 is directly gated by calcium ions. J Biol Chem 282:13180-13189

12. Gabev E, Kasianowicz J, Abbott T, McLaughlin S (1989) Binding of neomycin to phosphatidylinositol 4,5-bisphosphate (PIP2). Biochim Biophys Acta 979:105-112

13. Garcia-Morales P, Minami Y, Luong E, Klausner RD, Samelson LE (1990) Tyrosine phosphorylation in T cells is regulated by phosphatase activity: studies with phenylarsine oxide. Proc Natl Acad Sci U S A 87:9255-9259

14. Hardie RC, Raghu P, Moore S, Juusola M, Baines RA, Sweeney ST (2001) Calcium influx via TRP channels is required to maintain PIP2 levels in Drosophila photoreceptors. Neuron 30:149-159

15. Hecht D, Zick Y (1992) Selective inhibition of protein tyrosine phosphatase activities by $\mathrm{H} 2 \mathrm{O} 2$ and vanadate in vitro. Biochem Biophys Res Commun 188:773-779

16. Hilgemann DW, Feng S, Nasuhoglu C (2001) The complex and intriguing lives of PIP2 with ion channels and transporters. Sci STKE 2001:RE19

17. Hinman A, Chuang H-H, Bautista DM, Julius D (2007) TRP channel activation by reversible covalent modification. Proc Natl Acad Sci U S A 103:19564-19568

18. Huang CL, Feng S, Hilgemann DW (1998) Direct activation of inward rectifier potassium channels by PIP2 and its stabilization by Gbetagamma. Nature 391:803-806

19. Jordt SE, Bautista DM, Chuang HH, McKemy DD, Zygmunt PM, Hogestatt ED, Meng ID, Julius D (2004) Mustard oils and cannabinoids excite sensory nerve fibres through the TRP channel ANKTM1. Nature 427:260-265

20. Karashima Y, Damann N, Prenen J, Talavera K, Segal A, Voets T, Nilius B (2007) Bimodal action of menthol on the transient receptor potential channel TRPA1. J Neurosci 27:9874-9884

21. Katsura H, Obata K, Mizushima T, Yamanaka H, Kobayashi K, Dai Y, Fukuoka T, Tokunaga A, Sakagami M, Noguchi K (2006) Antisense knock down of TRPA1, but not TRPM8, alleviates cold hyperalgesia after spinal nerve ligation in rats. Exp Neurol 200:112-123

22. Khvotchev M, Sudhof TC (1998) Newly synthesized phosphatidylinositol phosphates are required for synaptic norepinephrine but not glutamate or gamma-aminobutyric acid (GABA) release. J Biol Chem 273:21451-21454

23. Kim D, Cavanaugh EJ (2007) Requirement of a soluble intracellular factor for activation of transient receptor potential A1 by pungent chemicals: role of inorganic polyphosphates. J Neurosci 27:6500-6509

24. Kwan KY, Allchorne AJ, Vollrath MA, Christensen AP, Zhang DS, Woolf CJ, Corey DP (2006) TRPA1 contributes to cold, mechanical, and chemical nociception but is not essential for haircell transduction. Neuron 50:277-289

25. Laux T, Fukami K, Thelen M, Golub T, Frey D, Caroni P (2000) GAP43, MARCKS, and CAP23 modulate $\mathrm{PI}(4,5) \mathrm{P}(2)$ at plasmalemmal rafts, and regulate cell cortex actin dynamics through a common mechanism. J Cell Biol 149:1455-1472

26. Lee J, Cha SK, Sun TJ, Huang CL (2005) PIP2 activates TRPV5 and releases its inhibition by intracellular $\mathrm{Mg}^{2+}$. J Gen Physiol 126:439-451

27. Liu B, Qin F (2005) Functional control of cold- and mentholsensitive TRPM8 ion channels by phosphatidylinositol 4,5bisphosphate. J Neurosci 25:1674-1681
28. Liu D, Liman ER (2003) Intracellular $\mathrm{Ca}^{2+}$ and the phospholipid PIP2 regulate the taste transduction ion channel TRPM5. Proc Natl Acad Sci U S A 100:15160-15165

29. Lopes CM, Zhang H, Rohacs T, Jin T, Yang J, Logothetis DE (2002) Alterations in conserved Kir channel-PIP2 interactions underlie channelopathies. Neuron 34:933-944

30. Lukacs V, Thyagarajan B, Varnai P, Balla A, Balla T, Rohacs T (2007) Dual regulation of TRPV1 by phosphoinositides. J Neurosci 27:7070-7080

31. Ma R, Li WP, Rundle D, Kong J, Akbarali HI, Tsiokas L (2005) $\mathrm{PKD} 2$ functions as an epidermal growth factor-activated plasma membrane channel. Mol Cell Biol 25:8285-8298

32. Macpherson L, Geierstanger BH, Viswanath V, Bandell M, Eid SR, Patapoutian A (2005) The pungency of garlic: activation of TRPA1 and TRPV1 in response to allicin. Curr Biol 15:929-934

33. Macpherson LJ, Dubin AE, Evans MJ, Marr F, Schultz PG, Cravatt BF, Patapoutian A (2007) Noxious compounds activate TRPA1 ion channels through covalent modification of cysteines. Nature 445:541-545

34. Macpherson LJ, Hwang SW, Miyamoto T, Dubin AE, Patapoutian A, Story GM (2006) More than cool: promiscuous relationships of menthol and other sensory compounds. Mol Cell Neurosci 32:335-343

35. Macpherson LJ, Xiao B, Kwan KY, Petrus MJ, Dubin AE, Hwang SW, Cravatt B, Corey DP, Patapoutian A (2007) An ion channel essential for sensing chemical damage. J Neurosciences 27:11412-11415

36. Madrid R, Donovan-Rodriguez T, Meseguer V, Acosta MC, Belmonte C, Viana F (2006) Contribution of TRPM8 channels to cold transduction in primary sensory neurons and peripheral nerve terminals. J Neurosci 26:12512-12525

37. Maher M, Ao H, Banke T, Nasser N, Wu N-T, Breitenbucher G, Chaplan S, Wickenden AD (2008) Activation of TRPA1 by farnesyl thiosalicylic acid. Mol Pharmacology 73:1225-1234

38. Nagata K, Duggan A, Kumar G, Garcia-Anoveros J (2005) Nociceptor and hair cell transducer properties of TRPA1, a channel for pain and hearing. J Neurosci 25:4052-4061

39. Nakanishi S, Catt KJ, Balla T (1995) A wortmannin-sensitive phosphatidylinositol 4-kinase that regulates hormone-sensitive pools of inositolphospholipids. Proc Natl Acad Sci U S A 92:5317-5321

40. Nilius B, Mahieu F, Prenen J, Janssens A, Owsianik G, Vennekens $\mathrm{R}$, Voets $\mathrm{T}$ (2006) The $\mathrm{Ca}^{2+}$-activated cation channel TRPM4 is regulated by phosphatidylinositol 4,5-biphosphate. EMBO J $25: 467-478$

41. Obata K, Katsura H, Mizushima T, Yamanaka H, Kobayashi K, Dai Y, Fukuoka T, Tokunaga A, Tominaga M, Noguchi K (2005) TRPA1 induced in sensory neurons contributes to cold hyperalgesia after inflammation and nerve injury. J Clin Invest 115:2393-2401

42. Otsuguro KI, Tang J, Tang Y, Xiao R, Freichel M, Tsvilovskyy V, Ito S, Flockerzi V, Zhu MX, Zholos AV (2008) Isoform-specific inhibition of TRPC4 channel by phosphatidylinositol 4,5-bisphosphate. J Biol Chem (in press)

43. Patapoutian A, Peier AM, Story GM, Viswanath V (2003) ThermoTRP channels and beyond: mechanisms of temperature sensation. Nat Rev Neurosci 4:529-539

44. Peterlin Z, Chesler A, Firestein S (2007) A painful Trp can be a bonding experience. Neuron 53:635-638

45. Rauch ME, Ferguson CG, Prestwich GD, Cafiso DS (2002) Myristoylated alanine-rich $\mathrm{C}$ kinase substrate (MARCKS) sequesters spin-labeled phosphatidylinositol 4,5-bisphosphate in lipid bilayers. J Biol Chem 277:14068-14076

46. Rohacs T (2007) Regulation of TRP channels by PIP2. Pflugers Arch 453:753-762

47. Rohacs T, Lopes CM, Michailidis I, Logothetis DE (2005) PI(4,5) $\mathrm{P}(2)$ regulates the activation and desensitization of TRPM8 channels through the TRP domain. Nat Neurosci 8:626-634 
48. Rohacs T, Nilius B (2007) Regulation of transient receptor potential (trp) channels by phosphoinositides. Pflügers Arch 455:157-168

49. Runnels LW, Yue L, Clapham DE (2002) The TRPM7 channel is inactivated by PIP(2) hydrolysis. Nat Cell Biol 4:329-336

50. Sawada Y, Hosokawa H, Hori A, Matsumura K, Kobayashi S (2007) Cold sensitivity of recombinant TRPA1 channels. Brain Res 1160:39-46

51. Sims C, Harvey RD (2004) Redox modulation of basal and betaadrenergically stimulated cardiac L-type $\mathrm{Ca}(2+)$ channel activity by phenylarsine oxide. Br J Pharmacol 142:797-807

52. Smith RJ, Sam LM, Justen JM, Bundy GL, Bala GA, Bleasdale JE (1990) Receptor-coupled signal transduction in human polymorphonuclear neutrophils: effects of a novel inhibitor of phospholipase C-dependent processes on cell responsiveness. J Pharmacol Exp Ther 253:688-697

53. Stein AT, Ufret-Vincenty CA, Hua L, Santana LF, Gordon SE (2006) Phosphoinositide 3-kinase binds to TRPV1 and mediates NGF-stimulated TRPV1 trafficking to the plasma membrane. J Gen Physiol 128:509-522

54. Stokes A, Wakano C, Koblan-Huberson M, Adra CN, Fleig A, Turner H (2006) TRPA1 is a substrate for de-ubiquitination by the tumor suppressor CYLD. Cell Signal 18:1584-1594

55. Story GM, Peier AM, Reeve AJ, Eid SR, Mosbacher J, Hricik TR, Earley TJ, Hergarden AC, Andersson DA, Hwang SW, McIntyre P, Jegla T, Bevan S, Patapoutian A (2003) ANKTM1, a TRP-like channel expressed in nociceptive neurons, is activated by cold temperatures. Cell 112:819-829

56. Suh BC, Hille B (2005) Regulation of ion channels by phosphatidylinositol 4,5-bisphosphate. Curr Opin Neurobiol 15:370-378
57. Suh BC, Hille B (2007) Electrostatic interaction of internal $\mathrm{Mg}^{2+}$ with membrane PIP2 seen with $\mathrm{KCNQ} \mathrm{K}^{+}$channels. J Gen Physiol 130:241-256

58. Taylor-Clark TE, Undem BJ, Macglashan Jr DW, Ghatta S, Carr MJ, McAlexander MA (2007) Prostaglandin-induced activation of nociceptive neurons via direct interaction with TRPA1. Mol Pharmacol 73:274-281

59. Vanhaesebroeck B, Leevers SJ, Ahmadi K, Timms J, Katso R, Driscoll PC, Woscholski R, Parker PJ, Waterfield MD (2001) Synthesis and function of 3-phosphorylated inositol lipids. Ann Rev Biochem 70:535-602

60. Webb J (1966) Arsenicals, vol. 3. Academic, New York

61. Wiedemann C, Schafer T, Burger MM, Sihra TS (1998) An essential role for a small synaptic vesicle-associated phosphatidylinositol 4-kinase in neurotransmitter release. J Neurosci 18:5594 5602

62. Zhang H, Craciun LC, Mirshahi T, Rohacs T, Lopes CM, Jin T, Logothetis DE (2003) PIP(2) activates KCNQ channels, and its hydrolysis underlies receptor-mediated inhibition of $\mathrm{M}$ currents. Neuron 37:963-975

63. Zhang Z, Okawa H, Wang Y, Liman ER (2005) Phosphatidylinositol 4,5-bisphosphate rescues TRPM4 channels from desensitization. J Biol Chem 280:39185-39192

64. Zheng Q, McFadden SC, Bobich JA (2004) Phosphatidylinositol 4,5-bisphosphate promotes both [3H]-noradrenaline and [14C]glutamate exocytosis from nerve endings. Neurochem Int 44:243250

65. Zurborg S, Yurgionas B, Jira JA, Caspani O, Heppenstall PA (2007) Direct activation of the ion channel TRPA1 by $\mathrm{Ca}(2+)$. Nat Neurosci 10:277-279 